\title{
INTRODUCTION \\ Juan de Betanzos and Inca Traditions
}

Juan de Betanzos was born in Spain but spent his adult life in the Viceroyalty of Peru. By far the most important source of information about him comes from his only remaining work, originally entitled Suma y narración de los Yngas ..., which has been abbreviated in English translation. In I 557 Juan de Betanzos finished his Narrative of the Incas, ${ }^{1}$ the single most authentic document of its kind. He drew on testimony of descendants of the Inca kings who still remembered the oral history and traditions of their ancestors. The colloquial style of his Narrative suggests that Betanzos had no more than a secondary school education. At the time, all university students had to learn Latin, but no trace of Latin can be found in his sentence construction, nor are there references to classical scholars, as in the works of educated writers like Bernabe Cobo. ${ }^{2}$ Betanzos reads more like the loose style of the soldier Pedro Pizarro, ${ }^{3}$ who only had a primary school education. However, as Betanzos explains in his introductory letter, his style was affected by the fact that he was translating his material, and he tried to do as literal a translation from his informants' Quechua as possible.

Juan de Betanzos became the most respected Quechua interpreter of the Viceroyalty of Peru. It took him several years to learn the Quechua language with no dictionaries, grammars, or textbooks. In his prologue, which is a letter to Viceroy Antonio de Mendoza written in 155 I, Betanzos explains that he spent six years of his "mocedad," or youth, on a commission preparing a Spanish-Quechua Doctrina christiana, a manual for priests that included the essentials of Christian beliefs, two vocabularies, prayers, and confessionals. Unfortunately, the manuscript has been lost. Nevertheless, the fact that the colonial government hired him for such an important assignment around I 544 shows that Betanzos had earned a reputation as the best Quechua interpreter and translator of that early colonial period. The Doctrina christiana (Lima, I 584 ), edited by Father Acosta, ${ }^{4}$ shows what a formidable task Betanzos undertook in pioneering the translation of Christian concepts foreign to the Quechua language.

Some time after I 54I, when Francisco Pizarro was assassinated, Juan de Betanzos married Doña Angelina Yupanque. At birth, she was taken to her uncle, the Inca Huayna Capac, who expressed his joy by calling her his mother. ${ }^{5}$ A year later the Inca named her Cuxirimay Ocllo and declared that she would 
marry his son Atahualpa. Thus in I 532, shortly before the conquest, Cuxirimay, just ten years old, was taken from her native Cuzco to the northern province of Caranque, where she married Atahualpa. During the battle of Cajamarca, when Pizarro took Atahualpa prisoner, she remained nearby at the Inca's camp. Later she stayed with the imprisoned Atahualpa in Cajamarca. After Atahualpa's execution, she took the Christian name Doña Angelina and returned to Cuzco. By around ${ }_{53} 8$ she had become the mistress of Francisco Pizarro. She bore him two boys, Juan and Francisco. Juan died very young, but Francisco grew up with the great mestizo writer known as the Inca Garcilaso, who remembered playing with him when they were both about nine years old. Garcilaso also remembered Doña Angelina's marriage to the interpreter Juan de Betanzos. ${ }^{6}$

Marriage to Angelina meant instant wealth for Betanzos because she had extensive land grants and property in the Cuzco area. Their daughter, Maria, married in Cuzco. Doña Angelina and her family provided Betanzos with his major source of information on Inca traditions. Though the Betanzos narrative reflects the brilliant memory of his wife and family, no one, not even Betanzos, ever told what she looked like or how she acted. This great woman, married to the last Inca king, taken as part of the plunder by the conquistador Pizarro, and used for her collective memory of the Inca saga, comes down to us as a shadowy figure behind the glitter of the men in her life.

In I 55 I Viceroy Antonio de Mendoza ordered Betanzos to prepare an account of Inca history and traditions. Betanzos indicates that he had finished at least up through Part I, chapter XIV, in I55I. The next year the viceroy died, but Betanzos kept to his Narrative until he finished rather abruptly in I 557. At this time he went to Lima to visit the new viceroy, Andres Hurtado de Mendoza, Marquis of Cañete. ${ }^{7}$ Betanzos asked to accompany an embassy to negotiate with the Inca Sayre Topa, head of the neo-Inca state northwest of Cuzco. The viceroy granted the request, and Betanzos spent several months trying to convince the Inca to come back under Spanish rule. Since Betanzos ended his Narrative shortly before going on this embassy, one must read other sources to find out how Inca Sayre Topa came to Lima, got a warm reception from the viceroy, and settled in Cuzco.

Evidently, Betanzos received some compensation for translating Christian doctrine, recording Inca traditions, and acting as interpreter. Although he gives no details about how much he was paid, the tone of his introductory letter to the viceroy is more that of a paid official than of an independent scholar. His insistence on how long and hard he would have to work to translate an authentic account of Inca history and traditions sounds like justification for a handsome honorarium. He seems to have preferred working as an interpreter, 
however, because he requested that the viceroy grant him a place with the embassy to Sayre Topa rather than seeking another job translating. After this assignment as an interpreter, Betanzos appears to have spent the rest of his life in Cuzco.

Betanzos divided Narrative of the Incas into two parts. Part I covers Inca history to the arrival of the Spaniards. Part II deals with the conquest, mainly from the point of view of the Incas, to I 557 . Betanzos's informants were from Atahualpa's family. They remembered some details of the mythological creation of the world by the god Viracocha and of the legendary foundation of Cuzco by Manco Capac (chaps. I-V). But from the second to the seventh Inca, the information dwindles to almost nothing (chap. V). The record of the eighth Inca relates mainly to his son, Pachacuti Inca Yupanque, the ninth Inca and great grandfather of Atahualpa (see Part I, chap. XXXII, on Pachacuti's lineage). Evidently, Doña Angelina and her family were taught epic poems detailing the life and times of their lineage from Pachacuti to Huayna Capac (see Part I, chaps. VIII, XIII, XVII, XIX, and XLI). These poems included speeches or statements by the main characters in the account. See, for example, Part I, chapters XXXI and XXXII, where Betanzos quotes Pachacuti giving instructions for his own funeral and making up a song about himself.

Pachacuti comes forth as a culture hero who defended Cuzco against overwhelming odds, successfully set out on military expeditions of conquest, and established the system of government, laws, city planning, and many of the Inca religious rites (chaps. VI-XXXII). His son Topa Inca and grandson Huayna Capac carried on the tradition of military exploits and expansion of the empire (chaps. XXXIII-XLVIII).

Part II has more of an eyewitness tone. Doña Angelina and her family saw or heard firsthand reports of the civil war between Huascar and her husband, Atahualpa. She remembered in great detail about Atahualpa's birth in Cuzco, his father's funeral, Atahualpa's military exploits and severity with anyone who dared to differ with him. Huascar, on the other hand, was born in a small town south of Cuzco, took scant interest in the military, openly slept with married women, killed their husbands if they complained, and drank to excess (chaps. I-XIV).

Doña Angelina, who, as a child of ten, spent the months after the conquest in 1532 in Atahualpa's camp, remembered the Incas' reactions to the Spaniards, their concern about whether the Spaniards were viracocha gods or mere men, whether they should be attacked, Atahualpa's treatment as a prisoner, and his death (chaps. XIX-XXVI). Betanzos also conferred with other eyewitnesses. He mentions speaking to Incas who were at Cajamarca near Atahualpa's litter during the initial battle of the conquest (Part II, chap. XXIII). The rest of 
his account covers events occurring shortly before and after Betanzos came to Peru. Betanzos probably got several firsthand reports for Manco Inca's siege of Cuzco in I 536, the neo-Inca state, Manco Inca's death in I 545, and the selection of Sayre Topa as Inca (chaps. XXIX-XXXIII). Betanzos brings his account to an abrupt end with a trip in 1557 to Lima, where he asked to be included in the embassy to Sayre Topa (chap. XXXIV).

Betanzos gives no indication that he aspired to publish his work. He did not even bother to update the introductory letter of $155 \mathrm{I}$ or to add a letter to the new viceroy in 1557 . Presumably, someone took the work back to Spain, but no one mentions it until Father Gregorio Garcia states in his work on the origin of the Indians (published in 1607 ) that he found Betanzos very valuable for Inca traditions. ${ }^{8}$ No one else seems to have used Betanzos until William Prescott, working in Boston, mentions him briefly in his History of the Conquest of Peru, published in $1847 .{ }^{9}$ Finally, Jiménez de la Espada edited the first edition from a manuscript still held in the library of El Escorial, Suma y narración de los Incas (Madrid, I 880). This incomplete manuscript includes only the introductory letter and eighteen chapters of Part I, which led scholars to date the manuscript at $155 \mathrm{I}^{10} \mathrm{~A}$ complete manuscript turned up in the library of the Fundación de Bartolomé March in Palma de Mallorca. ${ }^{11}$ María del Carmen Martín Rubio edited the first Spanish edition of this manuscript with the Editorial Atlas (Madrid, r987).

Unfortunately, this Atlas edition contains many transcription errors. For example, the word çapa always appears in the Palma manuscript with the $c$ (see folio $64 \mathrm{v}$, line 33 , Part I, chap. XXVII). Çapa or zapa means "unique," as in çapa inca, "unique Inca." The Atlas edition usually transcribes this word as capa, which is a different word in Quechua. ${ }^{12}$ Sometimes phrases come out garbled. For example, on folio 53v of the Palma manuscript, line 30 reads: "y que aeste tal fuese llamado çapsi churi que dice hijo del comun" (Part I, chap. XXI), which translates as "this one [child] would be called çapçichuri, which means son of the community." The Atlas edition has a meaningless phrase: "y que este çapçi fuese llamado tal Churi que dice hijo del comun." ${ }^{13}$ The Palma manuscript makes sense, for in Quechua çapsi means "community" or "people," churi means a "father's son." The passage refers to children considered to belong to the community because their mothers were prostitutes. These examples make it clear that any serious scholar interested in the Betanzos Narrative must work with the Palma manuscript (see the Note on the Translation).

The colloquial style of the Narrative suggests that Betanzos spoke with his informants in Quechua and then dictated his account to a scribe. This account was transcribed in the Palma manuscript with the regular lettering of an early 
seventeenth-century copyist or educated author, which makes it relatively easy to read. Each chapter has a heading in bold printing followed by a continuous stream of words, mostly in longhand, generally without periods and usually not divided into paragraphs. Phrases and sentences are repeatedly separated by the conjunction "y," meaning "and." In general, sentences are very long and contain several dependent clauses. Most lettering appears to be lowercase with random use of uppercase letters, though uppercase does appear at the beginning of some proper names. Written accent marks were not used. Each folio averages about 32 lines of about fourteen words. The few standard abbreviations can generally be recognized in context. The 152 folios make up 304 handwritten pages. Most doubtful passages in the Palma manuscript can be attributed to errors by the copyist. For example, in the Palma manuscript, $f$. I $5 \mathrm{v}$, line 8, a phrase has been omitted that appears in the Escorial manuscript (see Part I, IX n. I and XIV n. I). Punctuation marks and paragraphs have been used in the English translation to make it more readable.

Careful study of the Betanzos Narrative adds many insights into Inca history and traditions. For example, there has long been a controversy over Inca chronology. ${ }^{14}$ Traditionally, scholars have followed the work of the Inca Garcilaso in his Royal Commentaries, first published in $1609 .{ }^{15}$ This work places much of the expansion of the empire before the ninth Inca. In his classic study, "Inca Culture at the Time of the Spanish Conquest" (Handbook of South American Indians, vol. II, I946), John H. Rowe argues convincingly that the first eight Inca rulers conquered only towns near Cuzco and that Pachacuti provided the catalyst that turned a small regional state into a great empire. No matter how one interprets the Betanzos Narrative, it corroborates the theory of catalytic development under Pachacuti. ${ }^{16}$

Inca marriage customs have often been debated, especially marriage of the Inca rulers to their full sisters. The Betanzos Narrative indicates that the tenth Inca, Topa, was the first to marry his sister, Mama Ocllo. Whether she was his full or half-sister is not clarified. Topa's successor, Huayna Capac, seems to have done the same. However, Huayna Capac appears to be the only Inca ruler who came from the union of brother and sister. He arranged the marriage of Atahualpa to a cousin, Cuxirimay (see Part I, chap. XLVII, and Part II, chap. VI). Since Cuxirimay was only ten when the marriage took place, just before Atahualpa's installation as Inca in I 532, the union was probably never consummated and was more ceremonial than anything else. It suggests that Topa Inca's and Huayna Capac's marriages to sisters may also have been mainly ceremonial. All the Incas had numerous secondary wives for their sexual pleasure.

The Betanzos Narrative gives many other details about rites performed at 
birth, weaning, puberty, marriage, and death as well as about how the Incas performed many religious festivals. Many other important passages cover Inca administration, laws, social customs, the calendar, the post system, warfare, weapons, and engineering works. For example, the instructions for constructing a suspension bridge make it sound as though any well-trained gang of workers could do it. Furthermore, Betanzos states (Part I, chap. XLV) that he visited the great temple of Viracocha at Cachi, now better known as the temple of Racchi. His description of this temple coincides with recent studies by Graziano Gasparini and Luise Margolies in Inca Architecture (1980, trans. Patricia J. Lyon). ${ }^{17}$

Betanzos spins a dramatic and complex tale of revenge during the conquest period mainly from the point of view of the Incas. After the sudden death of Huayna Capac, the bitter civil war between his sons Huascar and Atahualpa emerges as a test of honor rivaling that of the proudest Spaniard. For example, Atahualpa's emissary of goodwill strikes Huascar as a traitor, so Huascar has him skinned and a drum made of his hide. Huascar's mother tries to no avail to keep the peace. After Atahualpa's generals win the war, he has Huascar's whole family killed - men, women, and children. Pregnant women have their wombs opened and their unborn children stripped from their bodies (Part II, chap. XIX). The arrival of the Spaniards leaves Atahualpa stunned at first, which explains the massacre at Cajamarca. However, by 1536 the Incas come to know the Spaniards. Manco Inca feels displaced by the Spaniards and, taking advantage of the rivalry between Pizarro and Almagro, takes his revenge by mounting a seige of Cuzco that lasts over a year and nearly breaks the Spaniards' hold on Peru (Part II, chap. XXXI).

Drawing from the most authentic sources, especially his Inca wife, Doña Angelina, Juan de Betanzos faithfully translated the history and traditions of the Inca rulers. Though never acknowledged as such, the feminine touch of Doña Angelina comes through in the details about rites of birth, coming of age, marriage, and death. The full and accurate details of this monumental work finally appear in English with this translation of the Palma manuscript. Both scholars and readers who study this Betanzos Narrative will reshape their views of Inca civilization. 